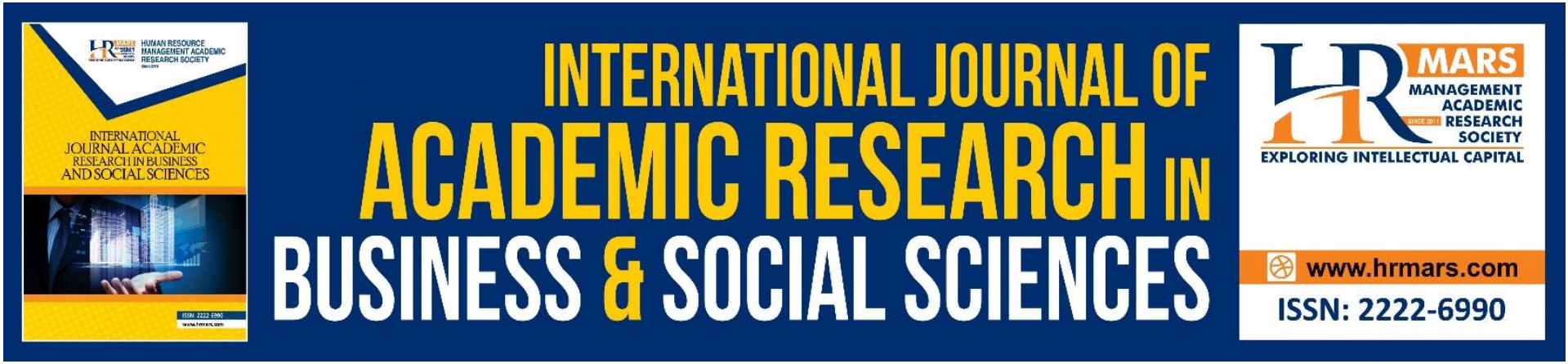

\title{
Designing Games for Islamic Values Inculcation of Pre- School Children: Jom Niat
}

\section{Nur Haifa Aqila Binti Norfazli, Hairulliza Mohamad Judi}

To Link this Article: http://dx.doi.org/10.6007/IJARBSS/v12-i1/11326

DOI:10.6007/IJARBSS/v12-i1/11326

Received: 06 November 2021, Revised: 02 December 2021, Accepted: 23 December 2021

Published Online: 01 January 2022

In-Text Citation: (Norfazli \& Judi, 2022)

To Cite this Article: Norfazli, N. H. A. B., \& Judi, H. M. (2022). Designing Games for Islamic Values Inculcation of Pre-School Children: Jom Niat. International Journal of Academic Research in Business and Social Sciences, 12(1), 1-10.

\section{Copyright: (c) 2022 The Author(s)}

Published by Human Resource Management Academic Research Society (www.hrmars.com)

This article is published under the Creative Commons Attribution (CC BY 4.0) license. Anyone may reproduce, distribute, translate and create derivative works of this article (for both commercial and non0-commercial purposes), subject to full attribution to the original publication and authors. The full terms of this license may be seen at: http://creativecommons.org/licences/by/4.0/legalcode

Vol. 12, No. 1, 2022, Pg. 1- 10

Full Terms \& Conditions of access and use can be found at http://hrmars.com/index.php/pages/detail/publication-ethics 


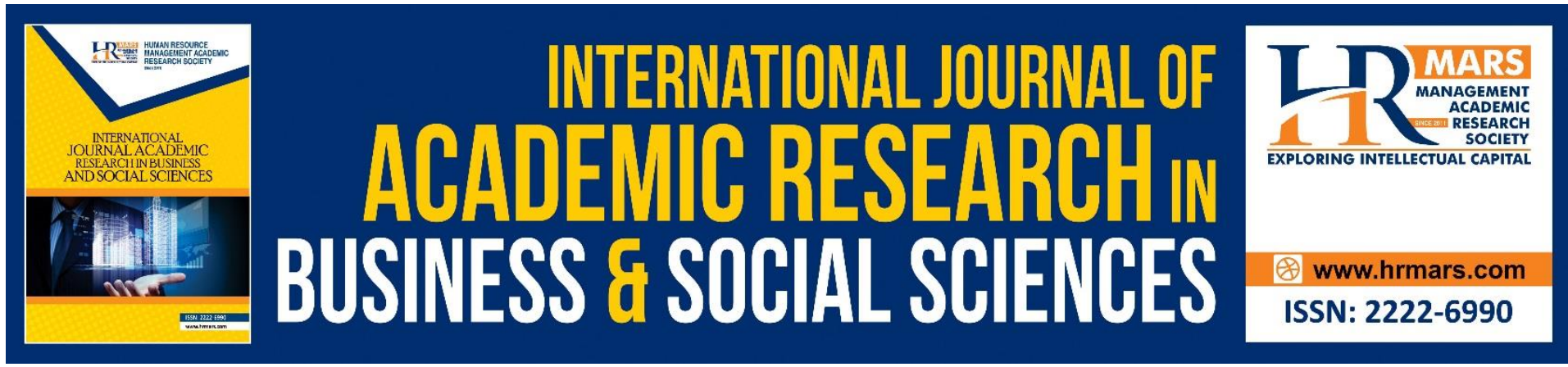

\title{
Designing Games for Islamic Values Inculcation of Pre-School Children: Jom Niat
}

\author{
Nur Haifa Aqila Binti Norfazli, Hairulliza Mohamad Judi \\ Faculty of Information Science and Technology, Universiti Kebangsaan Malaysia, 43600 UKM \\ Bangi, Selangor Darul Ehsan, Malaysia \\ Email: hmj.ftsm@gmail.com
}

\begin{abstract}
Serious games are not digital games that focus on entertainment and fun alone. On the other hand, serious games prioritise education that can increase interest and involvement among users, especially children in learning and teaching. Serious games can positively affect children by the impetus to transfer the knowledge and experience gained through games to real-world applications. Children development, especially at the preschool level, emphasises several essential elements for priority attention, including values and identity formation. Values and identity formation focus on inculcating an outstanding and well-established individual to be the backbone of a generation who can contribute and function well in society. The process of planning and developing a serious game featuring authentic values and identity formation learning content while maintaining entertainment and fun features is challenging. Thus, methodology and design guidelines are needed to help the game development team model a compelling game for the children. This paper addresses this challenge by planning and implementing a serious game framework to promote values and identity formation for children aged four to six. The results of this study are a serious game framework for values and identity formation of preschool children, based on the Cognitive Theory of Multimedia Learning principles. With a proper balance between game attributes and learning activities, the design of a serious game model includes game elements related to the readiness of preschool children to learn. The learning content applies the text that emulates the great values of the Prophet Muhammad peace and blessing upon him in nobly conducting daily life.
\end{abstract}

Keywords: Serious Game Framework, Values and Identity Formation, Preschool Children, Multimedia Cognitive.

\section{Introduction}

A serious game is a learning approach that is widely explored for children's education nowadays. In addition to contributing to learning in related fields, the serious game can increase children's attention and motivation through a fun learning environment (Tatli 2018). The development of serious game applications requires an appropriate framework to ensure that the elements of learning and games selected align with the potential of serious games (Abd El-Sattar, 2016; Nadiah and Norasikin, 2020). A serious game framework refers 
to a guide to serious game development operations to maximise the impact of serious games as a learning outcome (Catalano et al., 2014; Jamaatthuddin and Or-Kan, 2021; Paracha et al., 2020).

Values and identity formation are essential educational elements in children's holistic development. Values and identity formation aim to build an individual's superior identity who is the backbone of a generation of noble morals (Mastura and Farahwahida, 2020; Suhaimi and Natasha, 2018). The development of solid values among children prepares future generations to contribute and function well in society (Latifah et al., 2012; Shafie and Ling, 2017).

The age of preschool children is the transition from infancy to school age. Preschool children can learn and explore many things because they already have the necessary cognitive and affective levels at this age and can be developed slowly according to their potential (Lamrani et al., 2018; Lasiun, 2016). Although there are differences in policies and goals, Islamic and Western Education agree to develop civilised human character and values through values and identity formation from an early age (Atiyah et al., 2019).

Values and identity formation using serious game is inseparable from the research environment and learning goals embodied in learning theory. Learning theory serves as the guideline to remind the primary purpose of serious game development: to educate children in a stimulating and entertaining environment (Al-gharaibeh, 2021; Carvalho et al., 2015; Tatli, 2018). Cognitive Theory of Multimedia Learning suggests selecting multimedia elements to be used optimally in serious games to achieve learning goals (Mayer 2014; Moreno and Mayer 2016). This theory is suitable for use in serious games involving preschool children that emphasise the concept of real-life related solutions to quickly understand an idea based on the examples given (Greer et al., 2013; Sahrir et al., 2012).

Many of the earlier serious games research pay attention to the negative influence of playing games, but recently the positive impact has taken place (Christen et al., 2012). However, studies focusing on the use of games in teaching moral values, especially among preschool children, is still limited (Nadiah and Norasikin, 2020). Serious games may create meaningful learning environments to engage children with the interesting ethical concept inactive, stimulating, entertaining, practical, and fun atmosphere (Anwar et al., 2020). The research gaps and serious game potential stimulate this study to assist game developers regarding pertinent elements of game and learning content in the mentioned context.

The process of planning and developing a serious game featuring authentic values and identity formation learning content while maintaining entertainment and fun features is challenging (Abd El-Sattar, 2016). This paper attempts to address this challenge by suggesting game development design methodologies to effectively model values and identity formation. The serious game of values and identity formation applies the Cognitive Theory of Multimedia Learning. Therefore the objective of this paper is as follow:

- to propose a serious game framework to promote values and identity formation for children aged four to six.

\section{Serious Game Framework for Islamic Values Inculcation of Pre-School Children}

Values and identity formation focuses on building the identity of a superior and wellestablished individual to be the backbone of a generation that can contribute and function well in society. Values and identity formation applied to children as early as preschool age train them to practice morals and praiseworthy values while interacting as community members. This view is agreed upon by Islamic and Western Education approaches, although 
there are apparent differences in policy and goals (Atiyah et al., 2019). Generally, Islamic Education emphasises monotheism and divinity, aimed at gaining the pleasure of The Lord and highlighting success in this world and the hereafter (Munawar et al., 2012). On the other hand, Western Education promotes the ideology of human thought, which places the intellect in the highest place to find solutions to human problems.

Values and identity formation in the Islamic mould include the construction of morals and values encompassing his mind and heart, spiritual and physical (Atiyah et al., 2019). The structure of children's values refers to the sources of the Quran and Hadith (Ridzuan, 2017). Values formation requires time through various training and critical learning processes, including observation, thinking, knowledge and mental exercise (Hakimi, 2014). Children are like white cloth ready to be patterned (Sheikh and Ali, 2019), based on one mention of prophet Muhammad. It means that every child is born in a state of nature (clean), then both parents are responsible for shaping the child, whether Jewish, Christian or Magi.

Elements of values and identity formation are abundant in Hadith-sourced references. Children and adolescents and adults are encouraged to emulate the morals and values of the Prophet Muhammad saw in forming noble morals through the guidance of parents and teachers (Abdul Munir et al., 2013). The benefit of imitating this praiseworthy example is mainaly to get pleasant, healthy and balanced values, which obtains the pleasure of The Lord (Syukri and Abidin, 2018). This values and identity formation approach focuses on strengthening faith, enhancing acts of worship, and practising praiseworthy deeds (Shafie and Ling, 2017). Following the level of preschool children, they may abandon evil acts such as complaining while intensifying noble practices such as correcting intentions by learning and practising the relevant Hadith (Ridzuan, 2017).

The promotion of values and identity through serious games has the advantage of attracting children to strengthen their morals and values (Norhana et al., 2014). Serious games are different from ordinary digital games that only provide entertainment value to the users and educate and improve their skills while using them (Fleming et al., 2017). Serious games embody important messages conveyed in a natural environment so that essential details appear alive and worthy to be promoted (Lotfi et al., 2014).

An essential emphasis in the framework of a serious game is not only on learning materials but also on prioritising the game mechanism. For example, good avatars that match the high moral standard gives a good impression of the learning aim. Game design based on actual Islamic teachings positively influences users (Lotfi et al., 2014). Similarly, appropriate characters may support the learning task in the perspective of maximising the learning effects of empowering children's values (Ávila-pesántez et al., 2017).

The game mechanism is essential in developing serious games (Almeida and Simoes, 2019; Khaleel et al., 2016). Among 21 serious game elements, a few selected considers the objectives of serious games developed (Nursyahida et al., 2019). Thus, the number of ingredients used in a serious game does not help to improve its quality. The research was conducted by comparing equivalent studies.

The Cognitive Theory of Multimedia Learning underlines three assumptions (Mayer, 2014). First, the user visual and verbal process information differently through separate channels. Second, the user can only process a limited amount of information in each channel because of limited working memory capacity. Third, users actively process information by paying attention and integrating data to make it meaningful.

Five cognitive processes coordinate and integrate with working memory within a 
multimedia environment (Mayer and Moreno, 1998). The principles highlighted in the design of this multimedia instruction involve essential elements in teaching to be more attractive, including involving appropriate elements and colours (Mayer and Estrella, 2014). The five principles of learning design presented are: 1 ) Choose terms related to multimedia messages, 2) Select the visuals that are relevant to the multimedia message, 3) Build relationships between terms to build a coherent oral model, 4) Build relationships between images to develop a coherent graphic model, and 5) Integrate the oral model with graphics and with prior knowledge.

Cognitive Theory of Multimedia Learning recommends that multimedia elements be used optimally in learning. By considering real-life solutions for each concept, preschool children can understand an idea based on the examples. Adapting valuable learning materials may stimulate children to be proactive in learning (Hairulliza et al., 2019). Relevant learning materials are carefully selected and designed to ensure that they are helpful and appropriate in the context of life. Game elements may support auditory and visual materials to process learning messages well with limited memory capacity (Hess and Greer, 2016). Interaction also plays a vital role in values and identity formation to encourage children to participate and be directly involved in learning.

Based on the discussion presented, three components are essential in the serious game framework, as illustrated in Figure 1: the learning theory, learning content, and mechanics (Abd El-Sattar, 2016). Learning theories support the learning goals highlighted in game applications (Tatli, 2018). Learning content is the backbone of game applications to ensure learning materials are selected and delivered effectively (Aziz et al., 2019). The game's mechanism plays an essential role in ensuring the element of engagement to stimulate children to understand and practice the Hadis highlighted in serious game applications (Gallego-Durán et al., 2019).

\section{Serious Game Conceptual Model}

The conceptual model of Islamic Values Inculcation for Preschool children is illustrated in Figure 2. The conceptual model aims to provide users with an understanding of the model framework used in application development called Jom Niat. There are five aspects identified to develop the conceptual model of the Jom Niat prototype, namely serious game module, content source, interaction design, learning and design theory basis and animation technique. There are four selected modules in the prototype of Jom Niat, namely Patience part of faith, Respect for mother, Eating etiquette and Prayer, the soul of religion. The content sources for these four modules emerge from the Compilation of 20 Hadis conducted by Young Muslims Educational Center or Pusat Asuhan Tunas Islam (PASTI), one of many preschools in Malaysia. From four to six years old, preschool students in the centre learn from various learning materials, including the Compilation of 20 Hadis. The syllabus features the Islamic Values Inculcation representing three essential teachings: Belief Principle, Islamic Principle and Values Principle.

The interaction design consists of five-game elements: instructions, point score, time, options, and information. The selected game elements appear suitable for the intended learning goals to construct Islamic values and identity among preschool children. These children require clear and precise instruction to enjoy the game yet gain meaningful values and lessons in everyday life. Next, the point score aims to inform the children of the current achievement for their response in the game. Time element seeks to train children in using their time wisely to accomplish the mission. Option element offers the children some freedom 
to control the game according to their ability. Finally, the information element conveys essential messages from the game to the children. The learning and design theory guides the application to balance game fun and serious learning concepts. Value Sensitive principles promote high values, noble standards and humanity not only in the learned concepts but also in-game implementation. Animation technique applies the current trend in the digital game using three-dimensional animation.

\section{Discussion and Conclusions}

This study examines the methodology and design guidelines required to assist game development teams in modelling values effectively and identity formation games. Targeting children aged four to six, the serious game application promotes values and identity formation. The serious game framework applies the Cognitive Theory of Multimedia Learning as its first component to balance game attributes and learning activities (Aziz et al., 2019). The second component in the serious game framework emphasises the learning content (Hakimi, 2014). The selection of materials from the compilation of 20 Hadis emulates the great values of the Prophet Muhammad(Atiyah et al., 2019). Next, the third component includes game mechanisms to produce enjoyable games by providing game elements, interfaces and feedback (Khaleel et al., 2016). The choice of various game elements implemented in their respective studies fits the learning goals (Nursyahida et al., 2019). The exploitation of appropriate game elements aims to attract interest and create excitement to learn new concepts that are otherwise considered difficult and tedious (Fleming, 2017). The selected game elements appear e suitable for the intended learning goals to construct Islamic values and identity among preschool children, as games can be an effective and powerful tool for combining serious learning with enjoyment (Kokkalia et al., 2017). Values and identity formation serious game features subtle content by bringing the real-life environment to imitate the practices and advice attributed to the Prophet Muhammad (Abdul Munir et al., 2013). The selected hadith highlights practical features that are easy to implement in daily activities to encourage children to understand its contents and practice it in life (Lukman Hakimi, 2014).

In conclusion, serious game design and development is not an easy task. This paper proposes a framework for the design and development of serious games for preschool children's values and identity formation. It introduces cognitive multimedia as a framework that helps game development teams plan effective games and learn through these two-way mechanisms. This framework is proposed to develop serious games called Jom Niat. It aims to facilitate the acquisition of Islamic moral principles applied in the Hadith of the Prophet Muhammad for children aged four to six.

The theoretical and contextual contributions of this paper are described as the following. The theoretical contribution offers the black box opening between serious games and preschool children education and combines learning theory to explain the relationship between educational surroundings and learning content design. The contextual contribution of this paper proposes guidelines to developers that pertinent elements of game and learning content contribute to the engagement of moral inculcation, which promote children in developing understanding and application of morals in daily life. 


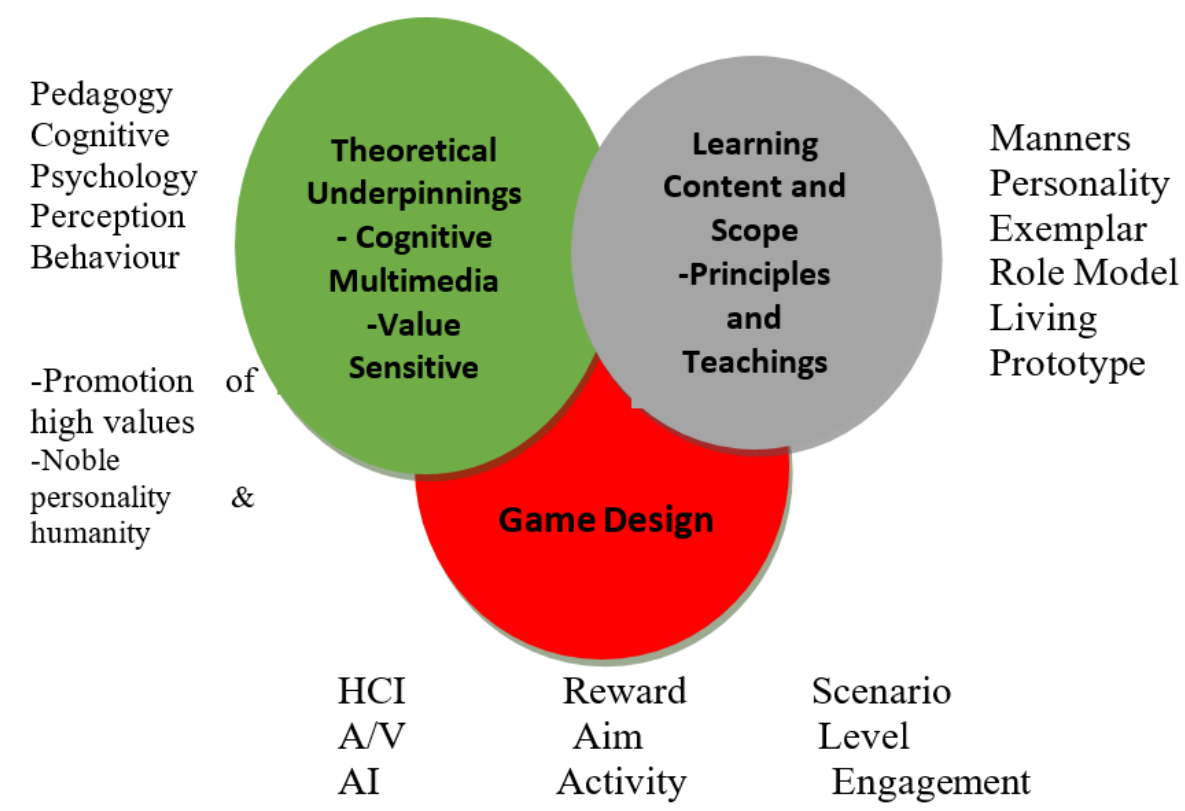

Fig. 1. Serious game framework for Islamic Values Inculcation

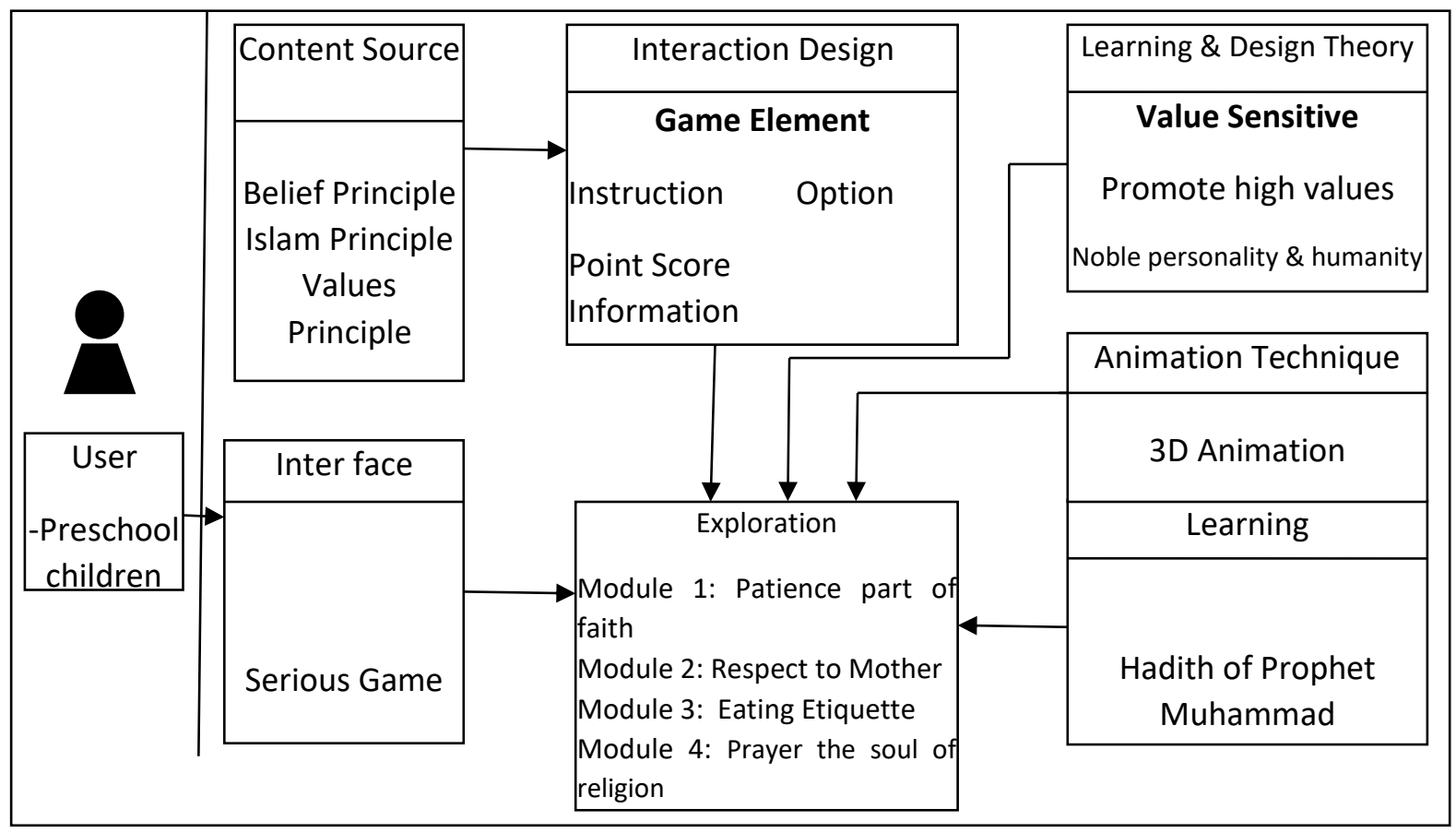

Fig. 2. Conceptual model of Islamic Values Inculcation for Preschool children

\section{Acknowledgement}

This work was supported by the Universiti Kebangsaan Malaysia under Grant GGP-2019-022.

\section{References}

Abd El-Sattar, H. K. H. (2016). Learning Islamic principles with serious games. ACM International Conference on Advances in Computer Entertainment Technology. https://doi.org/10.1145/3001773.3001800

Al-gharaibeh, R. S. (2021). Knowledge Sharing Framework: a Game-Theoretic Approach. Journal of the Knowledge Economy. 
Almeida, F., \& Simoes, J. (2019). The role of serious games, gamification and industry 4.0 tools in the education 4.0 paradigm. Contemporary Educational Technology, 10(2), 120-136. https://doi.org/10.30935/cet.554469

Ávila-pesántez, D., Rivera, L. A., \& Alban, M. S. (2017). Approaches for Serious Game Design : A Systematic Literature Review. December.

Aziz, M. S. A., Auyphorn, P., \& Hamzah, M. S. (2019). Exploring the use of digital games as a persuasive tool in teaching Islamic knowledge for muslim children. International Journal of Advanced Computer Science and Applications, 10(6), 109-113. https://doi.org/10.14569/ijacsa.2019.0100616

Aziz, M. S. A., Auyphorn, P., Hamzah, M. S., \& Othman, R. (2019). Types of digital games with Islamic values. Journal of Computational and Theoretical Nanoscience, 16(3), 11001103. https://doi.org/10.1166/jctn.2019.8002

Carvalho, M. B., Bellotti, F., Berta, R., De Gloria, A., Sedano, C. I., Hauge, J. B., Hu, J., \& Rauterberg, M. (2015). An activity theory-based model for serious games analysis and conceptual design. Computers and Education, 87(April), 166-181.

https://doi.org/10.1016/j.compedu.2015.03.023

Catalano, C. E., Luccini, A. M., \& Mortara, M. (2014). Guidelines for an effective design of serious games. International Journal of Serious Games, 1(1). https://doi.org/10.17083/ijsg.v1i1.8

Fleming, T. (2017). Serious Games and Gamification for Mental Health : Current Status and Promising Directions. Frontiers in Psychology, 7. https://doi.org/10.3389/fpsyt.2016.00215

Fleming, T. M., Bavin, L., Stasiak, K., Hermansson-Webb, E., Merry, S. N., Cheek, C., Lucassen, M., Lau, H. M., Pollmuller, B., \& Hetrick, S. (2017). Serious games and gamification for mental health: Current status and promising directions. Frontiers in Psychiatry, 7(JAN). https://doi.org/10.3389/fpsyt.2016.00215

Gallego-Durán, F. J., Villagrá-Arnedo, C. J., Satorre-Cuerda, R., Compañ-Rosique, P., MolinaCarmona, R., \& Llorens-Largo, F. (2019). A Guide for Game-Design-Based Gamification. Informatics, 6(4), 49. https://doi.org/10.3390/informatics6040049

Greer, D. L., Crutchfield, S. A., \& Woods, K. L. (2013). Cognitive Theory of Multimedia Learning, Instructional Design Principles, and Students with Learning Disabilities in Computerbased and Online Learning Environments. Journal of Education, 193(2), 41-50. https://doi.org/10.1177/002205741319300205

Hairulliza, M. J., Iksan, Z. H., \& Ashaari, N. S. (2019). Cognitive Visual Support Design for Efficient Data Analytics Learning Based on Meaningful Reception Learning Theory. 4, 194-198.

Hess, A., \& Greer, K. (2016). Designing for Engagement : Using the ADDIE Model to Integrate High-Impact Practices into an Online Information Literacy Course. Communications in Information Literacy, 10(2), 264-282.

Jamaatthuddin, N. M., \& Or-Kan, S. (2021). An Examination on the Students' Perceptions towards the Effectiveness of Using Game-Based Learning in Learning the English Language for Students in Higher Education. International Journal of Academic Research in Business and Social Sciences, 11(8), 1689-1714. https://doi.org/10.6007/IJARBSS/v11i8/10891

Khaleel, F. L., Noraidah, S. A., Meriam, T. S. T. W., \& Amirah, I. (2016). Gamification elements for learning applications. International Journal on Advanced Science, Engineering and Information Technology, 6(6), 868-874. https://doi.org/10.18517/ijaseit.6.6.1379 
Kokkalia, G., Drigas, A., Economou, A., Roussos, P., \& Choli, S. (2017). The use of serious games in preschool education. International Journal of Emerging Technologies in Learning, 12(11), 15-27. https://doi.org/10.3991/ijet.v12i11.6991

Lamrani, R., Abdelwahed, E. H., Chraibi, S., Qassimi, S., \& Hafidi, M. (2018). Gamification and serious games based learning for early childhood in rural areas. In Communications in Computer and Information Science (Vol. 929). Springer International Publishing. https://doi.org/10.1007/978-3-030-02852-7_7

Lasiun, M. (2016). Keberkesanan Kaedah Visualisasi: Meningkatkan Keupayaan Menyelesaikan Masalah Matematik Berayat. International Seminar on Generating Knowledge Through Research, 687-698.

Latifah, A. M., Nasyrudin, W. A., \& Hidayah, N. A. Z. (2012). Penerapan Nilai Murni dan Pembentukan Jati Diri Kanak-Kanak Prasekolah Melalui Penggunaan Multimedia. Jurnal Hadhari, 51-65.

Lotfi, E., Amine, B., Fatiha, E., \& Mohammed, B. (2014). Learning to Pray, Islamic Children's Game. International Conference on Multimedia Computing and Systems.

Hakimi, L. A. (2014). Persepsi Pelajar terhadap Kurikulum Pendidikan Islam Politeknik dalam Pembentukan Sahsiah Muslim. Jurnal Pendidikan Malaysia, 39(2), 133-140. https://doi.org/10.17576/JPEN-2014-\%x

Mastura, B., \& Farahwahida, M. Y. (2020). Pendidikan Keibubapaan Melalui Santunan Fitrah Nabi Ya'qub A.S Dan Pendekatannya Bagi Menangani Salah Laku Remaja. UMRAN International Journal of Islamic and Civilizational Studies, 2, 113-123.

Mayer, R. E. (2014). Cognitive theory of multimedia learning. In The Cambridge handbook of multimedia learning (pp. 43-71). https://doi.org/http://dx.doi.org/10.1017/СВ09781139547369

Mayer, R. E., \& Estrella, G. (2014). Benefits of emotional design in multimedia instruction. Learning and Instruction, 33, 12-18. https://doi.org/10.1016/j.learninstruc.2014.02.004

Mayer, R. E., \& Moreno, R. (1998). A Cognitive Theory of Multimedia Learning : Implications for Design Principles. In Annual Meeting of the ACM SIGCHI Conference on Human Factors in Computing Systems, January 2005.

Suhaimi, M., \& Natasha, N. A. R. (2018). Hubungan antara Tingkah laku Keibubapaan, Tekanan Psikologikal dengan Tahap Kesihatan Mental dalam kalangan Penjaga Kanak-Kanak Autisme. Jurnal Psikologi Malaysia, 32(4), 123-132.

Moreno, R., \& Mayer, R. E. (2016). Cognitive Principles of Multimedia Learning: The Role of Modality and Cognitive Principles of Multimedia Learning: The Role of Modality and Contiguity. June 1999. https://doi.org/10.1037/0022-0663.91.2.358

Ridzuan, M. Z. (2017). Pembentukan Sahsiah Anak Soleh Berdasarkan Surah Luqman di Sekolah Rendah Islam Hidayah [Universiti Teknologi Malaysia]. https://doi.org/10.1017/CBO9781107415324.004

Nadiah, R., \& Norasikin, F. (2020). The Importance of Game Development Framework (GDF): Proposing an Islamic Game Development Framework with Sustainability Features. International Journal of Academic Research in Business and Social Sciences, 10(3), 633644. https://doi.org/10.6007/ijarbss/v10-i3/7078

Norhana, Y., Rias, R. M., \& Yusoff, E. H. (2014). Serious Games in Mental Health Treatment : Review of Literature. Knowledge Management International Conference (KMICe) 2014, 595-599.

Nursyahida, M., Ismail, A., \& Muda, Z. (2019). Designing model of serious game for flood safety training. International Journal of Advanced Computer Science and Applications, 
10(5), 331-339. https://doi.org/10.14569/ijacsa.2019.0100541

Paracha, S., Hall, L., Clawson, K., \& Mitsche, N. (2020). Design, development, and usability of a virtual environment on moral, social, and emotional leaning. International Journal of Virtual and Personal Learning Environments, 10(2), 50-65. https://doi.org/10.4018/IJVPLE.2020070104

Sahrir, M. S., Alias, N. A., Ismail, Z., \& Osman, N. (2012). Employing Design and Development Research ( DDR ) Approaches in the Design and Development of Online Arabic Vocabulary Learning Games Prototype. TOJET: The Turkish Online Journal of Educational Technology, 11(2), 108-119.

Shafie, S. Bin, \& Ling, Y. (2017). Pembentukan sahsiah berkualiti melalui penghayatan kurikulum Pengajian Islam: Satu kajian korelasi di politeknik. National Conference on Thinking Culture, 1-9. https://doi.org/10.1002/pol.1985.170230908

Sheikh, S., \& Ali, M. (2019). Al-Ghazali's Aims and Objectives of Islamic Education. Journal of Education and Educational Development, 6(1), 111-125. https://doi.org/10.22555/joeed.v6i1.2033

Atiyah, S. A., Samhani, I., Nurfaizatul, A., \& Abdul Rahman, O. (2019). Psikologi Pembangunan Kanak-Kanak: Perkaitan Antara Psikologi Pendidikan Barat dan Psikologi Pendidikan Islam. Journal of Islamic Educational Research (JIER), 4(1), 14-23. https://doi.org/10.1017/СB09781107415324.004

Syukri, M., \& Abidin, Z. (2018). Pendekatan Psikoterapi Islam Terhadap Kanak-kanak Muslim Autistik Pendekatan Psikoterapi Islam Terhadap Kanak-kanak Muslim Autistik. 88(May), 65-73. https://doi.org/10.17576/akad-2018-8801-05

Tatli, Z. (2018). Traditional and Digital Game Preferences of Children: A CHAID Analysis on Middle School Students. Contemporary Educational Technology, 9(1), 105. 